\title{
Education on community empowerment in prevention of Covid-19 to the community Laut Dendang village, Percut Sei Tuan district Deli Serdang regency
}

\author{
Mardiningsih $^{1}$, Saib Suwilo ${ }^{1}$, Herman Mawengkang ${ }^{1}$, Sutarman $^{1}$, Marpongahtun ${ }^{2}$ \\ ${ }^{1}$ Department of Mathematics, Faculty of Mathematics and Science, Universitas Sumatera \\ Utara, Medan, Indonesia \\ ${ }^{1}$ Department of Chemistry, Faculty of Mathematics and Science, Universitas Sumatera Utara, \\ Medan, Indonesia
}

*Email: mardiningsih@usu.ac.id

\begin{abstract}
Community Service Activities carried out by the Service Team are intended to achieve the output target of reducing the spread of covid-19 in the people of Laut Dendang Village. The community service team conducts outreach regarding improving the quality of health and education in this village, in this case the Village Head, Hamlet Head, and PKK women become participants in this outreach, so that further all participants can socialize the issue of the importance of preventing Covid-19 and how to do it. prevention. It is hoped that the improvement of the quality of health in this village can be a lesson for the village community to understand and implement all knowledge or rules in reducing or stopping the spread of this deadly virus. This service is aimed at Community Service for the 2020 USU Lecturer Service Scheme is to solve problems together with the community through observation, problem identification, problem formulation, preparation of alternative solutions and evaluation of their implementation.
\end{abstract}

Keywords: Online, Information Technology, Community Service

\begin{abstract}
Abstrak
Kegiatan Pengabdian Kepada Masyarakat, yang dilakukan oleh Tim Pengabdian dimaksudkan untuk mencapai target luaran perbaikan berkurangnya penyebaran covid-19 masyarakat Desa Laut Dendang. Tim pengabdian melakukan penyuluhan mengenai perbaikan kualitas kesehatan dan pendidikan di desa ini, dalam hal ini Bapak Kepala Desa, Kepala Dusun, dan Ibu-ibu PKK menjadi peserta dalam penyuluhan ini, agar selanjutnya semua peserta dapat mensosialisasikan masalah pentingnya pencegahan covid-19 dan bagaimana cara pencegahannya. Perbaikan kualitas kesehatan di desa ini diharapkan dapat menjadi pembelajaran bagi masyarakat desa untuk memahani dan melaksanakan semua pengetahuan atau aturan aturan dalam mengurangi atau memberhentikan berkembangnya penularan virus yang mematikan ini.. Pengabdian ini bertujuan Pengabdian Masyarakat Skema Dosen Mengabdi USU 2020 ini adalah Memecahkan permasalahan bersama dengan masyarakat melalui observasi, identifikasi masalah, perumusan masalah, penyusunan solusi alternatif dan evaluasi penerapannya.
\end{abstract}

Kata Kunci: Daring, Teknologi Informasi, Pengabdian

\section{PENDAHULUAN}

Saat ini Pemerintah Kabupaten Deli Serdang dan Pemerintah Kota Medan dan masih terus fokus mnghadapi situasi penyebaran virus covid-19. Hal ini disebabkan kasus penyebaran virus covid19 di Deli Serdang dan kota Medan terus mengalami peningkatan. Oleh karena itu dibutuhkan suatu penyuluhan dengan pendekatan kepada masyarakat desa tentang bagaimana cara virus ini berkembang, sehingga masyarakat benar mengerti tentang pentingnya pengetahuan untuk mengatasi penyebaran virus ini. Dengan adanya penyuluhan dan pembagian masker serta sanitizer, diharapkan masyarakat dapat ikut serta dalam penanganan penyebaran virus ini dan kesadaran untuk itu lebih meningkat. 
Dalam hal ini diperlukan sinergitas yang baik dari berbagai pihak elemen masyarakat. Masih ada masyarakat yang belum memiliki pemahaman yang baik tentang bagaimana penangan penyebaran virus ini. Di sisi yang lain yang sudah faham bahwa untuk tetap tinggal dirumah adalah hal yang paling mendukung dalam hal mengurangi penyebaran virus ini, tetapi karena keterbatasan ekonomi terpaksa mereka harus keluar rumah untuk mencari nafkah. Untuk masyarakat yang harus keluar rumah, diwajbkan untuk menggunakan alat pelindung diri seperti masker dan sanitizer. Maka dari permasalahan-permasalahan diatas diperlukan peran pergururan tingggi melalui staf pengajarnya untuk menangani dansudah banyak membantu dalam meyelesaikan masalah yang dihadapi saat ini, melalui kegiatan Pengabdian Kepada Masyarakat.

Dengan adanya pengabdian masyarakat ini diharapkan Desa Laut Dendang kecamatan Percut Sei Tuan kabupaten Deli Serdang, dapat menanggulangi dan mengurangi permasalahan kesehatan, khususnya mengurangi penularan virus corona yang dampaknya sangat merusak atau mengganggu di sektor perekonomian Desa dan sector pendidikan khususnya serta umumnya mengganggu sektor perekonomian dan pendidikan suatu Negara

\section{METODE PELAKSANAAN}

Kegiatan Pengabdian Kepada Masyarakat, yang diusulkan oleh Tim pengusul Pengabdian dimaksudkan untuk mencapai target luaran perbaikan berkurangnya penyebaran covid-19 masyarakat Desa Laut Dendang khususnya dan seluruh masyarakat Indonesia umumnya. Untuk ini diharapkan kepala desa kepala dusun,ibu-ibu PKK dapat mensosialisaikan masalah pentingnya pencegahan covid19 dan bagaimana cara pencegahannya, setelah tim pengabdian melakukan penyuluhan Perbaikan kualitas kesehatan di desa ini diharapkan dapat menjadi pembelajaran bagi masyarakat desa Untuk memahani dan melaksanakan semua pengetahuan atau aturan aturan dalam mengurangi atau memberhentikan berkembangnya penularan virus yang mematikan ini.

Identifikasi masalah desa menjadi bahan pedoman sebagai perencanaan untuk menentukan program kegiatan yang tepat dan sesuai dengan permasalahan yang ada di Desa Laut Dendang

Masalah 1 : Pemahaman masyarakat dan khususnya anak anak dan ibu rumah tangga tentang

Solusi : Sosialisasi pentingnya bagaimana anak dapat berkembang dan berprestasi

Metode Pelaksanaan : Dengan melakukan diskusi dan sharing informasi kepada beberapa masyarakat dan Pejabat Desa pada tanggal 15 Juli 2020

Masalah 2 : Minat, kebersihan, komunikasi anak-anak sekolah dasar di desa ini masih kurang dan perlu motivasi dan pembelajaran yang menarik

Solusi : Perlu penyuluhan bagaimana cara untuk membangkitkan minat belajar dan menggali potensi anak-anak usia dini dan sekolah dasar

Meode Pelaksanaan : Penyuluhan kepada Sekretaris Desa dan staf Desa, pimpinan setiap dusun atau kepala Dusun, pengurus karang taruna dan Ibu ibu pengurus PKK tentang bagaimana menjaga kesehatan, khususnya bagaimana cara memutus mata rantai virus covid-19, dan memanfaatkan tanaman disekitar untuk pembuatan antiseptic, yang berguna untuk menjaga penularan virus, serta membagi masker, sanitizer, vitamin C, poster,kepada peserta dan banner dan poster kepada kantor Kepala Desa, serta pembagian sembako.

\subsection{Tahapan Kegiatan}

a. Tim pengabdian masyarakat berdiskusi dengan Bapak Kepala Desa dan sekretaris Desa serta aparat desa dan beberapa masyarakat Desa, Tanggal 14 Juli 2020

b. Tim pengabdian masyarakat memberi Penyuluhan/ceramah tentang cara pencegahan dan penularan covid-19 sehingga kita dapat memutus mata rantai penularan covid-19.

c. Mahasiswa KKN Penyuluhan/ceramah tentang pembuatan sanitizer dari daun sirih dan jeruk nipis

d. Pembagian alat pelindung diri dari Tim pengabdian masyarakat

e. Pembagian alat pelindung diri dari tujuh orang Mahasiswa KKN.

Pelaksanaan Pengabdian ini akan dilakukan dalam dua tahapan besar, yaitu: 
1. Pelaksanaan Forum Group Discussion (FGD) serta Pelatihan Penyiapan RPP

FGD dilaksanakan untuk curah pendapat yang akan memberikan masukan kepada Pelaksana Pengabdian terkait masalah-masalah utama di Desa Laut Dendang. Kegiatan ini dilanjutkan dengan pelatihan penyiapan RPP yang dihadiri oleh semua guru di Desa Laut Dendang. Tujuannya agar para guru dapat menyusun RPP berbasis pembelajaran aktif. Kegiatan ini akan dilakukan oleh Pelaksana Pengabdian sendiri. Kegiatan akan dilaksanakan pada Bulan Juli 2020.

2. Pelatihan Pembuatan Bahan Ajar berbasis Teknologi Informasi.

Pelatihan ini akan difokuskan kepada Guru Mata Pelajaran dengan bidang masing-masing. Peserta pelatihan dikelompokkan ke dalam beberapa kelompok, sehingga bisa fokus langsung menggunakan komputer. Kegiatan ini akan dilaksanakan pada bulan Agustus atau September 2020 .

Metode yang akan dilakukan pada pelaksanaan pengabdian ini adalah :

1. Mengumpulkan informasi yang diambil dari buku atau kurikulum pelajaran yang akan dibuat aplikasi pembelajarannya.

2. Melakukan identifikasi bagaimana membuat agar materi yang dikaji menjadi lebih mudah dipelajari oleh Desa Laut Dendang.

3. Untuk menarik minat belajar siswa pada materi ini, akan dibuat aplikasi pembelajaran yang materinya dikemas seefisien mungkin, sehingga siswa dapat berinteraksi dengan aplikasi tersebut.

4. Melakukan perancangan aplikasi pembelajaran, mulai dari membuat tampilan aplikasi, penyusunan materi, latihan dan soal.

5. Setelah perancangan rampung dan diperoleh hasil yang maksimal, maka dilakukan pembagian aplikasi ini ke sekolah dan membuat pelatihan /workshop kepada guru matematika atau siswa.

\section{HASIL DAN PEMBAHASAN}

Kegiatan dan hasil yang dicapai pada pengabdian kepada masyarakat di Desa Laut Dendang Kecamatan Percut Sei Tuan Kabupaten Deli Serdang, dilakukan melalui kegiatan Diskusi dengan Kepala Desa, sekretaris desa dan kepala Dusun 1 sampai dengan 9, Ibu Kepala Desa dan Ibu -Ibu PKK.

Awalnya tim menanyakan masalah pemahaman dan pengetahuan tentang cara pencegahan dan penularan covid-19 sehingga kita dapat memutus mata rantai penularan covid-19. Selanjutnya Tim pengabdian memberi masukan dan menjelaskan pentingnya pengetahuan ini. Dalam kegiatan ini tim pengabdian mayarakat menjelaskan tentang. Indikator keberhasilan: pihak pemerintahan desa akan memberi perintah kepada bapak bapak kepala dusun serta ibu ibu pengurus PKK desa untuk melakukan penyuluhan kepada anggota masyarakat disetiap dusun, begitu juga pengurus PKK melakukan penyuluhan kepada seluruh anggota PKK.

1. Pengarahan dan kata sambutan dari Bapak Kepala Desa, kepada semua peserta .

Bapak Kepala Desa mengucapkan terimakasih kepada tim pengabdian dan peserta, dan dilanjutkan dengan memberikan masukan agar semua peserta menikuti penyuluhan ini dengan hidmah, agar nantinya dapat meneruskan ke semua anggota yang dipimpin.

a. Penyuluhan dari tim pengabdian

b. Capaian keberhasilan kegiatan: Masyarakat khususnya aparat desa dan semua kepala dusun serta ibu-ibu PKK menyambut dan menerima, dengan diadakannya diadakan penyuluhan tentang bagaimana cara dan usaha yang dilakukan untuk memutus mata rantai penularan covid-19.

c. Indikator keberhasilan: pihak pemerintahan desa akan memberi perintah kepada bapak bapak kepala dusun serta ibu ibu pengurus PKK desa untuk melakukan penyuluhan kepada anggota masyarakat disetiap dusun, begitu juga pengurus PKK melakukan penyuluhan kepada seluruh anggota PKK. 
d. Tim pengabdian kepada masyarakat dengan ora beberapa mahasiswa yang saat ini berada di Medan, diskusi tentang bagaimana cara mengurangi atau memutus tali rantai covid-19 ini, dan mengajak peserta untuk mau selalu mengikuti protokol kesehatan, terutama kesehatan dimasa pandemi covid-19 ini.. Hasil yang diperoreh adalah adanya "diskusi yang menyenangkan" yang dilakukan mahasiswa dan tim pengabdian masyarakat.

\section{KESIMPULAN (CONCLUSION)}

Tim pengabdian melakukan penyuluhan mengenai perbaikan kualitas kesehatan dan pendidikan di desa ini, dalam hal ini Bapak Kepala Desa, Kepala Dusun, dan Ibu-ibu PKK menjadi peserta dalam penyuluhan ini, agar selanjutnya semua peserta dapat mensosialisasikan masalah pentingnya pencegahan covid-19 dan bagaimana cara pencegahannya. Perbaikan kualitas kesehatan di desa ini diharapkan dapat menjadi pembelajaran bagi masyarakat desa untuk memahani dan melaksanakan semua pengetahuan atau aturan dalam mengurangi atau memberhentikan berkembangnya penularan virus yang mematikan ini.

Awalnya dengan melakukan diskusi dan sharing informasi kepada beberapa masyarakat dan Pejabat Desa pada tanggal 13 Juli 2020, dimana tim menanyakan masalah pemahaman dan pengetahuan tentang cara pencegahan dan penularan covid-19 sehingga kita dapat memutus mata rantai penularan covid-19. Selanjutnya tanggal 4 Agustus 2020, Tim pengabdian dengan tujuh mahasiswa bimbingan DPL KKN memberi masukan dan menjelaskan pentingnya pengetahuan ini. Dalam kegiatan ini tim pengabdian mayarakat menjelaskan tentang, Apa itu covid-19, Bagaimana cara penularan covid-19 ? Tanda dan gejala covid-19 ?, Cara Pencegahan covid-19 ?, Siapa yang Paling rentan ?, Apa itu OTG,ODP dan PDP ?, Apa yang dilakukan setelah bepergian ?, Tahapan mencuci tangan Cara memakai masker dan handsanitizer yang benar.Dengan menyerahkan banner, poster dan cendera mata untuk kantor kepala desa, serta menyerahkan masker, hand sanitizer kepada semua kepala dusun agar dapat dibagikan kepada masing-masing anggotanya atau masyarakat desa laut Dendang, juga diharapkan bahwa semua masyarakat Desa Laut Dendang dapat memahami dan peduli serta melaksanakan semua pengetahuan atau aturan dalam mengurangi atau memberhentikan berkembangnya penularan virus covid-19 ini.

Capaian keberhasilan kegiatan: Masyarakat khususnya aparat desa dan semua kepala dusun serta ibu-ibu PKK menyambut dan menerima, jika diadakan penyuluhan tentang bagaimana cara dan usaha yang dilakukan untuk memutus mata rantai penularan covid-19.

\section{UCAPAN TERIMAKASIH}

Terimakasih kepada Rektor USU dan LPPM USU yang telah memberikan dana pengabdian tahun 2020 Skema Mono Tahun Dosen Mengabdi.

\section{DAFTAR PUSTAKA}

HomeEdition. 2005, Macromedia flash Profesional 8 help, Macromedia Inc

Juhaeri. 2009. Pengantar Multimedia untuk Media Pembelajaran bagian I, Ilmu Komputer.

Retno, Margono dan Bambang Eka Purnama. ISSN 1979 - 9330. Study of Interaktif Recognition Letter and Number For Children With Computer Multimedia. Indonesian jurnal on Computer Science - Speed (IJCSS) 4 Vol. 3 Nomor 1 Agustus 2008

Script Island. 2008. Panduan Mudah Membuat Animasi. Jakarta: Media Kita.

Tulus, Sawaluddin, T.J. Marpaung, dan M.R. Syahputra. 2018. Making Learning Teaching Materials in School Based On Information And Communication Technology. Abdimas Talenta. Vol. 3 No. 2 pp. 202-2016 